\title{
「玄関後退」型住宅成立に伴う屋根形式および住宅外観の変容過程
}

\author{
一金沢市におけるケース・スタディ No.7一
}

\section{STUDY ON THE MORPHOLOGY OF THE EXTERNAL APPEARANCE OF THE TRADITIONAL TOWN HOUSING IN THE BUILT-UP AREA WHERE LOWER SAMURAI CLASSES HAD INHABITED IN THE EDO ERA. -Case study in Kanazawa city, Part 7-}

玉置伸俉*, 增田達男**

Shingo TAMAKI and Tatsuo MASUTA

\begin{abstract}
In this paper, the external appearance of the traditional town housing and its evolution processes are analyzed. conclusions are as follows,

1. The main roof style of the housing type with the receding entrance (Genkan-kotai type) had been developing from the saddle roof to the saddle with the pent roof ("Irimoya").

2. The roof of the kitchen transformed from the lean-to roof to the saddle roof, as the kitchen had been projecting from the main structure.

3. The roof style of the vestibule hadideveloped from the lean-to roof to the saddle with the pent roof.

4. The morphological development of the external appearance of the traditional town housing had been motivated by the resident's aspiration for keeping his status.
\end{abstract}

Keywords : external appearance, roof style, evolution process, traditional town house

\section{はじめに}

一連の本研究注”において旧武士居住地における昭和

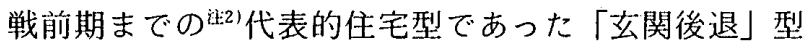
住宅の成立について，主として次の点を明らかにした。 1. 明治後期からはじまる「玄関後退」型は旧下級武士 居住地における「玄関」型を祖型として成立した。

2.「玄関後退」型は，正式のザシキを確保するための 住宅の 2 階建て化を直接の動機として発生した。

3. 玄関の後退は住宅の 2 階化の過程で必要になった階 段を「玄関」型における「小間」の位置に設け，その結 果，玄関回りを整理したことに起因している。

4. 一方，ナガシの張り出しは，住宅間口の縮小化過程 に対応しつつ，かつチャノマおよびナガシ面積を確保し ようとする必然的結果として生み出された。

以上は，主としてデータの統計的処理と住宅平面上の 分析から実証したものであった。

本稿では，1節では主屋と下屋に関連して屋根形式お よび構造面について，2 節では住宅前部のナガシとゲン カンの屋根形式について分析することを通し，「玄関後 退」型成立に伴う住宅外観上の変容を明らかにする。3
節では，前稿までにおいて触れることのなかった昭和戦 前期までの具体的な住まい方について, 若干の補充調查 結果を「補遺」として紹介することにより，「玄関後退」 型成立の直接の契機となった 2 階建て化の要因を分析・ 補強している。

最後に, 改めて「立関後退」型成立の意味を整理する ことにより,一連の本研究を結んでいる。

\section{1. 屋根形式とその変容}

本節では，前稿までに述べてきた住宅前部の変容と主 屋の屋根形式との関連について検討する。

表一1は，時期別・間口別に屋根形式を集計したもの である。全体を通してみると平入りと妻入り（入団屋を 含む) がほぼ半ばしているが，大正期から昭和戦前期に かけて平入りが漸减する傾向がわずかに認められる。

しかし，これを間口別にみると明瞭な特徴が認められ る。間口を 3 間以下の小間口と 3.5 間以上の相対的に大 間口に分けてみると, 小間口の場合は $64.4 \%$ は平入り であるが， 3.5 間以上になると $28.9 \%$ と激減する。ま たこれを時期別にみると，3 間以下の小間口の場合，明
* 福井大学 教授. I博

** 金沢工業大学 講師·工修
Fukui Univ., Prof. Dr. Eng.

Kanazawa Institute of Technology, Lecturer, M. Eng. 
表一1 主屋の屋根形式の変遷

\begin{tabular}{|c|c|c|c|c|c|c|c|c|c|c|c|c|c|c|c|c|c|c|c|c|}
\hline \multirow{2}{*}{\multicolumn{2}{|c|}{$\begin{array}{l}\text { 住宅平面型 } \\
\text { 住宅間口 } \\
\end{array}$}} & \multicolumn{7}{|c|}{ 「茹䦥，型 } & \multicolumn{6}{|c|}{ 「立瞰侵遇」梨 } & \multicolumn{6}{|c|}{ 合 㔚 } \\
\hline & & \begin{tabular}{|l|l|}
2 & 2 \\
\end{tabular} & 2.5 & \begin{tabular}{l|l}
3 & 3 \\
\end{tabular} & 3.5 & & 4.5 & 站 & \begin{tabular}{|l|l|}
2 & 2.5 \\
\end{tabular} & 3 & 3.5 & 4 & 4.5 & 时 & \begin{tabular}{l|l|l}
2 & 2. \\
\end{tabular} & \begin{tabular}{l|l}
.5 & 3 \\
\end{tabular} & \begin{tabular}{|l|l}
3 & 3.5 \\
\end{tabular} & \begin{tabular}{|l|l|}
5 & 4 \\
\end{tabular} & 4.5 & \begin{tabular}{|l|} 
Sit \\
\end{tabular} \\
\hline $\begin{array}{l}\text { 明 } \\
\text { 治 }\end{array}$ & 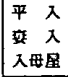 & 1 & & $\begin{array}{l}2 \\
1\end{array}$ & $\begin{array}{l}3 \\
2\end{array}$ & & 5 & $\begin{array}{l}16 \\
14\end{array}$ & 1 & 1 & 1 & 3 & $\begin{array}{l}1 \\
1\end{array}$ & $\begin{array}{l}4 \\
4 \\
1\end{array}$ & 1 & & $\begin{array}{ll}3 & 4 \\
1 & 2\end{array}$ & $\begin{array}{l}5 \\
8\end{array}$ & $\begin{array}{l}3 \\
6\end{array}$ & $\begin{array}{r}20 \\
18 \\
1 \\
\end{array}$ \\
\hline 期 & 时 & 1 & 4 & 3 & 5 & 9 & 0 & 30 & 1 & 1 & 1 & 4 & 2 & 9 & 15 & 54 & $4 \quad 6$ & 13 & 10 & 39 \\
\hline $\begin{array}{l}\text { 大 } \\
\text { 正 }\end{array}$ & 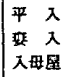 & & 3 & & $\begin{array}{l}1 \\
1\end{array}$ & 1 & 1 & 10 & 4 & $\begin{array}{l}4 \\
1 \\
1\end{array}$ & 3 & 1 & $\begin{array}{l}1 \\
1 \\
1\end{array}$ & $\begin{array}{r}10 \\
12 \\
3\end{array}$ & & $\begin{array}{ll}7 & 8 \\
4 & 2 \\
& 1\end{array}$ & $\begin{array}{ll}8 & 1 \\
2 & 4 \\
1 & \end{array}$ & $\begin{array}{l}2 \\
4 \\
1\end{array}$ & $\begin{array}{l}2 \\
1 \\
2\end{array}$ & $\begin{array}{r}20 \\
15 \\
4\end{array}$ \\
\hline 期 & 暗 & & 3 & 5 & 2 & 2 & 2 & 14 & 8 & 6 & 3 & 5 & 3 & 25 & 11 & 111 & 15 & 7 & 5 & 39 \\
\hline $\begin{array}{l}\text { 照 } \\
\text { 犁 }\end{array}$ & 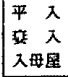 & 1 & $\begin{array}{l}5 \\
4 \\
1 \\
\end{array}$ & $\begin{array}{l}5 \\
3\end{array}$ & $\begin{array}{l}2 \\
1 \\
1\end{array}$ & $\begin{array}{l}1 \\
1 \\
1\end{array}$ & 1 & $\begin{array}{r}14 \\
6 \\
7\end{array}$ & $\begin{array}{r}15 \\
6 .\end{array}$ & $\begin{array}{l}9 \\
5 \\
4 \\
\end{array}$ & $\begin{array}{l}2 \\
5 \\
6 \\
\end{array}$ & 4 & $\begin{array}{l}5 \\
1 \\
\end{array}$ & $\begin{array}{l}30 \\
30 \\
15 \\
\end{array}$ & $\begin{array}{rr}120 \\
& 10 \\
& \\
\end{array}$ & $\begin{array}{rr}0 & 14 \\
0 & 5 \\
1 & 7 \\
\end{array}$ & $\begin{array}{ll}4 & 4 \\
5 & 6 \\
7 & 7 \\
\end{array}$ & $\begin{array}{r}5 \\
10 \\
5 \\
\end{array}$ & $\begin{array}{l}5 \\
2 \\
\end{array}$ & $\begin{array}{l}44 \\
36 \\
22 \\
\end{array}$ \\
\hline Hi & 影 & 11 & 10 & 8 & 4 & 3 & 1 & 27 & 21 & 18 & 13 & 17 & 6 & 75 & 131 & 126 & $6 \quad 17$ & 20 & 7 & 102 \\
\hline 合 & \begin{tabular}{|ll} 
平 & $\lambda$ \\
पे & $\lambda$ \\
$\lambda$ & $\lambda$ \\
$\lambda$
\end{tabular} & 2 & $\begin{array}{l}11 \\
5 \\
1\end{array}$ & $\begin{array}{r}11 \\
2 \\
3\end{array}$ & $\begin{array}{l}6 \\
4 \\
1\end{array}$ & $\begin{array}{l}6 \\
7 \\
1\end{array}$ & 2 & $\begin{array}{r}40 \\
23 \\
8\end{array}$ & $\begin{array}{l}20 \\
10\end{array}$ & $\begin{array}{r}14 \\
6 \\
5\end{array}$ & $\begin{array}{l}3 \\
8 \\
6\end{array}$ & 6 & $\begin{array}{l}1 \\
7 \\
3\end{array}$ & $\begin{array}{l}44 \\
46 \\
19\end{array}$ & $\begin{array}{rr}2 & 31 \\
& 15 \\
& \\
& 15\end{array}$ & $\begin{array}{rr}1 & 25 \\
5 & 8 \\
1 & 8\end{array}$ & $\begin{array}{rr}5 & 9 \\
8 & 12 \\
8 & 7\end{array}$ & $\begin{array}{r}12 \\
22 \\
6\end{array}$ & $\begin{array}{r}5 \\
12 \\
5\end{array}$ & \begin{tabular}{|l}
84 \\
69 \\
27
\end{tabular} \\
\hline 壾 & at & 2 & 17 & 161 & 11 & 14 & 11 & 71 & 30 & 25 & 17 & 26 & 11 & 109 & $\begin{array}{ll}2 & 4 ?\end{array}$ & 741 & 128 & 40 & 22 & 180 \\
\hline
\end{tabular}

治期においては $8 / 10=80 \%$ が平入りであるが，大正期 では $15 / 22=68 \%$, 昭和戦前期では $35 / 55=60 \%$ と平 入りは減少する。同様に 3.5 間間口以上においても明治 期の $12 / 29=41 \%$, ついで $5 / 17=29 \%, 9 / 40=20 \%$ と 減少する。

すなわち，旧武士居住地においては平入りと妻入りが 相半ばしているように見えるが，小間口住宅の場合は建 てづまりと関連して平入りが多く，かつ時代の経過の中 で小間口住宅が増加してきたために平入りの絶対数は多 くなる。しかしそれにもかかわらず，小間口住宅におい ても経年的に平入りの比率が減少し，妻入り化が進んで きたことを示している。

一方， 3.5 間間口以上についてみると，明治期におい ては $17 / 29=59 \%$ が妻入り（入母屋を含む）であった。 それが大正期になると $12 / 17=71 \%$ となり，昭和戦前 期では $35 / 44=80 \%$ 之相対的に大間口住宅の場合，も ともと妻入りが多かったものが時代の経過の中でさらに 妻入り化が進んできたことを示している。

住宅型別には，明治期主流であった「玄関」型におい ては，平入り，妻入りが半ばしており， 3.5 間間口以上 に限っても平入りが $10 / 22=45 \%$, 妻入りが $12 / 22=55$ $\%$ と大差ない。

これが大正期になると, 当時台頭してきた「玄関後退」 型の場合, 3.5 間間口以上では妻入りが $9 / 11=82 \%$ を 占め, 昭和戦前期は $30 / 36=83 \%$ を示している。 3 間間 口以下の場合でも妻入りは, 大正期で $6 / 14=43 \%$, 昭 和戦前期は $15 / 38=40 \%$ といずれも 4 割程度を占めて いる。

このように妻入り化は，「玄関後退」型の台頭とより 関連して現象してきている。

さらに注目される現象として主屋屋根の入母屋化があ る。妻入りの中で, 切妻屋根から入母屋屋根の変化は大 正期頃より現われ，昭和戦前期では $22 / 102=22 \%$ に達 するようになる。中でも 3.5 間間口以上に限ると $14 / 44$ $=32 \%$ 之約 $1 / 3$ は入母屋住宅となる。すなわち屋根形 式においても，時代を追うごとに格式性をもつ意匠が好
まれるようになってきたことを示しているといえよう。 なお，金沢市（前田藩）における旧武士階層の住宅は 一般的には妻入り形式であっだ3)。しかしながら現存 する足軽住宅の遺構は妻入り形式と平入り形式に, 地域 によって明確に 2 分されており ${ }^{\sharp 44}$ ，足軽間の身分上の 差異が現れているものと推察される。

以上の主屋屋根形状における全体的傾向を背景とし て, 次に, 明治初期の代表的タイプである「玄関」型の $\lceil 2 \cdot 2 \cdot 2$ 構成」について, 主屋の屋根とゲンカンおよ びナガシ部分の屋根の関係を検討する。

主屋が妻入り形式の場合は, 図一1 の立体図に示すよ うに, 前方に 1.5 間の下屋として張り出した形態をとる (写真一 1 参照)。この前面下屋には，モデル平面図-2

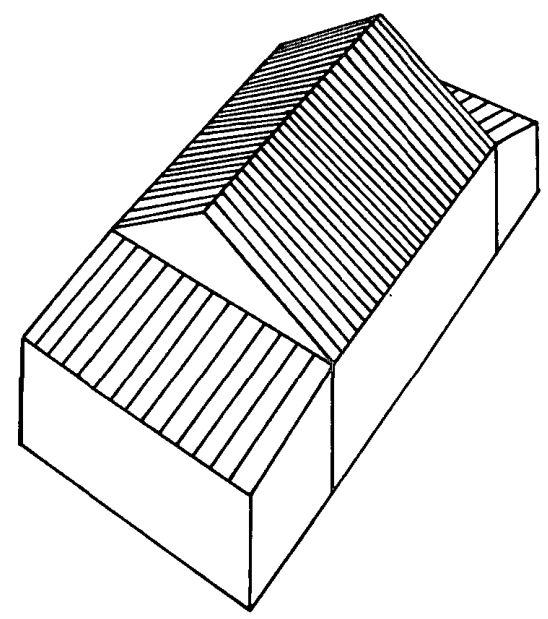

図一1 立体図・「玄関」型 平屋・妻入り

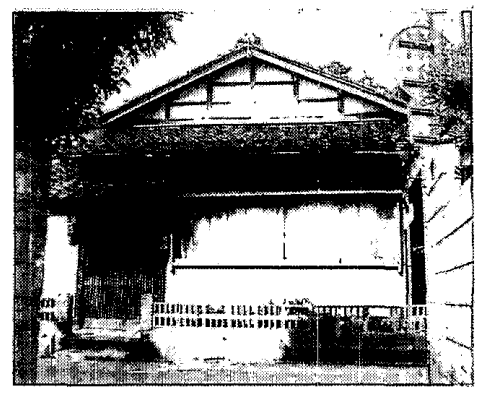

写真一1「玄関」型・平屋・妻入り形式
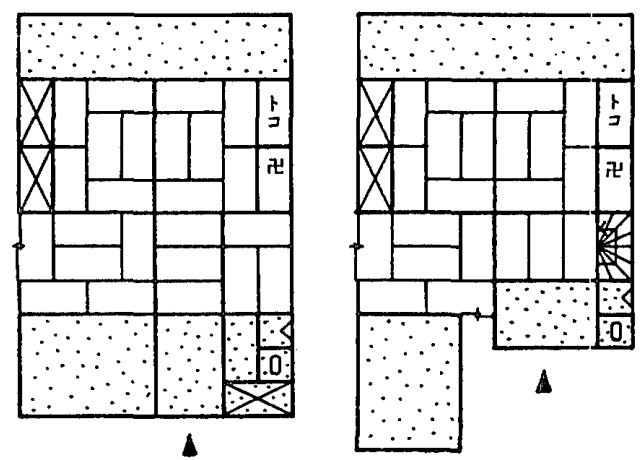

図一2「玄関」型および「玄関後退」型・「2・2・2 構成」にお ける“ドマ”と上げ床の関係 
からも明らかなように，ゲンカン，ナガシおよび便所が 含まれる。すなわち，本来的には“ドマ”一で構成されて いた設備・サービス的空間は下屋，一方，上げ床部分で あった居住室空間は主屋と，明確に分節されている。

一方，主屋が平入り形式の場合は，図一3の立体図に 示すように前部のゲンカン・ナガシ・便所も大屋根の下 に組み込まれ，外観上，下屋は現れない.(写真一2参照)。 しかしながら，実際に小屋組を内部から仰ぎ見ると（図 -4 参照), 奥行方向への主要な梁 (ノボリ梁补) は居 住室部のみに架構されている。すなわち身舎梁間は図一 2 における上げ床部分のみであり，ナガシ等（図一 2 に おける “ドマ”部分）の上部は主屋屋根の延長線上には

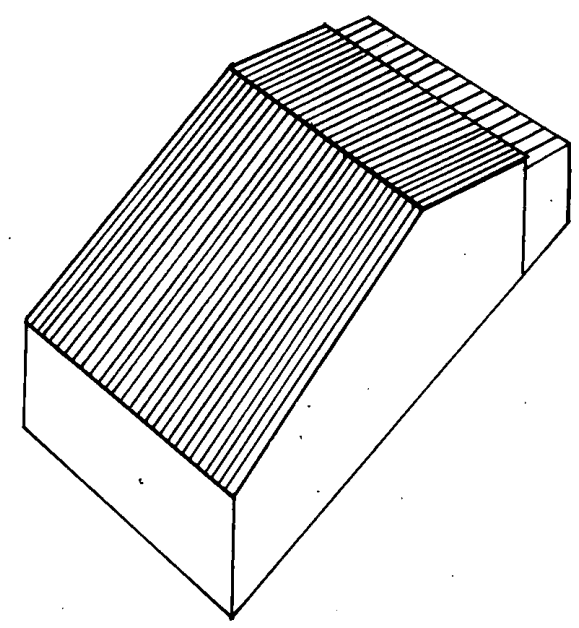

图一3 立体図・「玄関」型 平屋・平入り

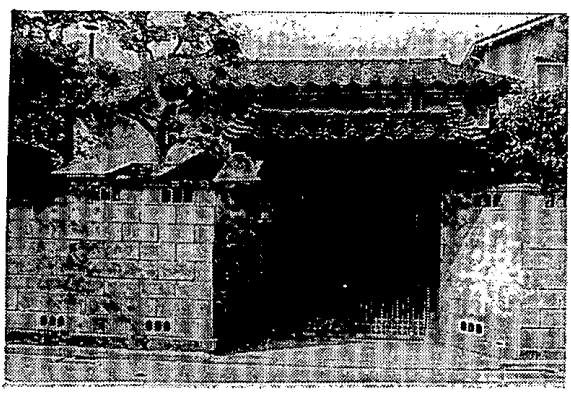

写真一2「玄関」型・平屋・平入り形式

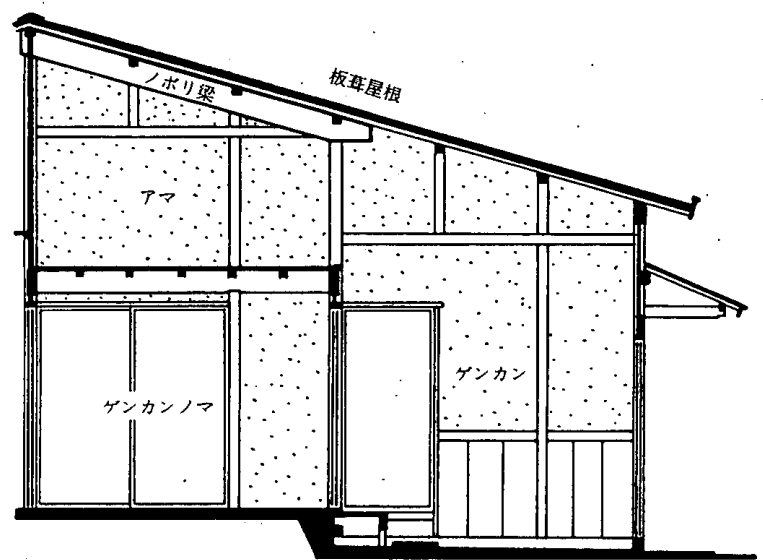

図一4 平入り大屋根形式のノボリ梁構造と“ドマ”部分の関係
あるものの, 構造的には明らかに下屋であることが分か る。なお, 主屋の妻入り, 平入りを問わず，ナガシの上 部は天井が張られず，下から直接小屋組を見上げること のできる吹き抜けの空間となっている。ナガシにおける 煙や湿気，匂いなどに配虑した空間形態であるが，同時 に平入りの場合も，ナガシは大屋根下に含まれてはいる ものの, 妻入りの下屋の場合と質的には全く変わらない 空間内容・形態であることを示している。

なお，図一1，3における住宅後部の 1 間の下屋庇は工 ン(廊下) と土エンにかかるものである。

以上の関係は住宅が 2 階化した場合に端的に表現され る。すなわち，妻入りの場合は図一5の立体図に示すよ うに，主屋部だけが 2 階化し，前面下屋はそのままの形 で残される。なお，この段階で，2 階の切妻屋根下の破 風面を貫之束を格子状に組み真壁風にみせる独特の意

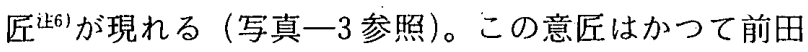
藩における板蕞きの武家住宅にみられたものであり，そ れが 2 階化の段階で破風面が大きく目立つため, 強く意 識されるようになってきた結果を反映しているものと考 えられる。

一方, 平入りの場合も図一6の立体図に示すように, 元来の“ドマ”部分が妻入りの場合と同様に下屋となり, 居住室部分のみ 2 階建てとなる (写真一 4 参照)。

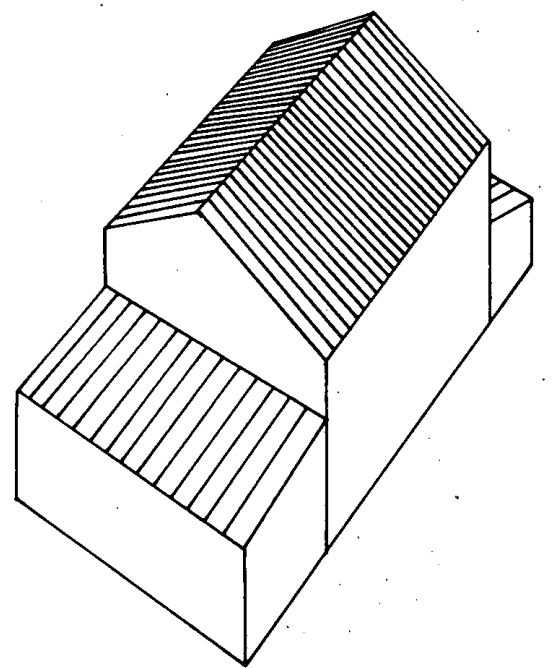

図一5 立体図・「玄関」型 2 階建て・妻入り

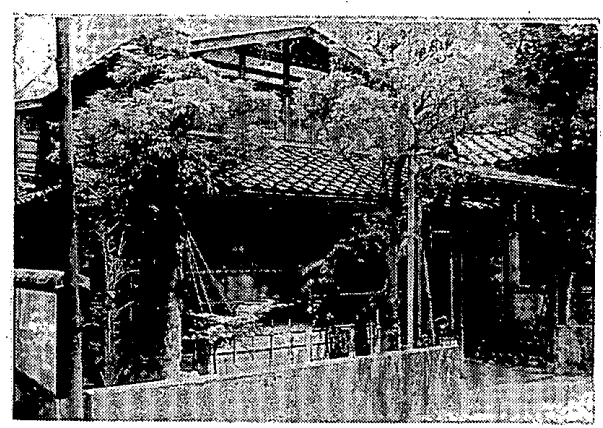

写真一 3 「玄関」型・2 階建て・嫶入りト屋形式 


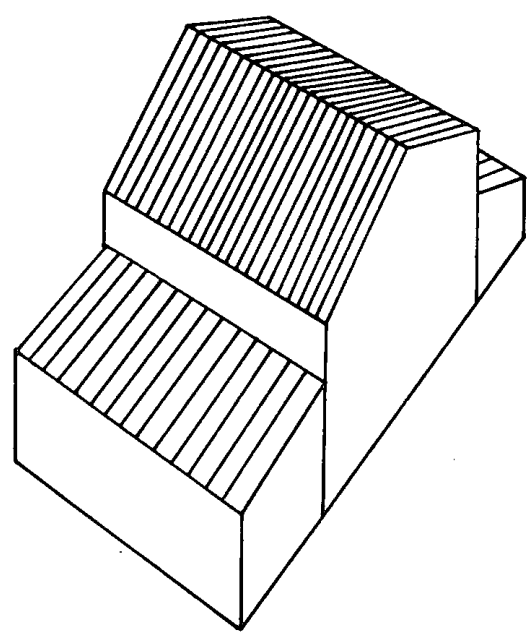

図一 6 立体図・「玄関」型 2 階建て・平入り

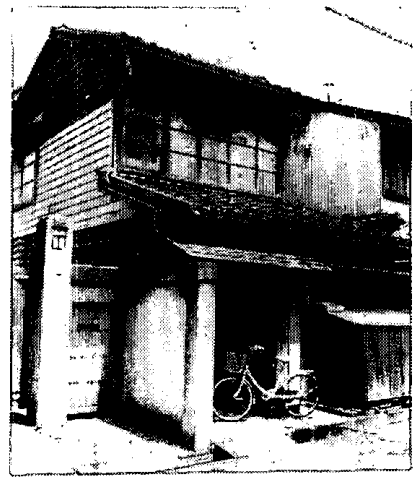

写真一4 明治後期の典型的な「玄関」型・ 2 階建て・平入り下 屋形式

しかしながら，上記図一 5,6 のように前部下屋が張り 出した状態で 2 階化するものは実際はきわめて少数であ る。すなわち，前稿までに示してきたように 2 階建ての 成立は同時に「玄関後退」型の成立と言ってよく，「玄 関後退」型は本稿の定義上，玄関を主屋内部に半間喰い 込ませる形（図一2，右図参照）で後退させるとともに， $\lceil 2 \cdot 2 \cdot 2\rfloor$ 構成や「2・2・1」構成の場合はナガシ形状 を間口×奥行きを $2.0 \times 1.5$ 間から $1.5 \times 2.0$ 間に形状変 化し，主屋前面部に張り出させるものであった。これを 屋根架構の面からみれば,下屋という形態はなじまない。 2 間に張り出したナガシを下屋で架構すればその先端部 の天井高は低いものになってしまう。また，天井高を確 保しつつ図一 5,6 の模式図に示す下屋形態をとると, そ の立上がりによって 2 階前面の壁面を塞いでいき， 2 階 空を前面に設ける場合には，室内側からは腰高になると ともに空せいは低いものとなる。事実，「玄関」型で 2 階の場合，2 階前面に窓を設けず，側面に設ける（隣家 との関係において採光・プライバシーなど不利である が）ものも認められる。

これを解決する手段として「ツノヤ泣つ」形式が採用 された。図一7に示すようにナガシはツノヤとして突き 出す形態をとっており，これによってナガシ前面部の天

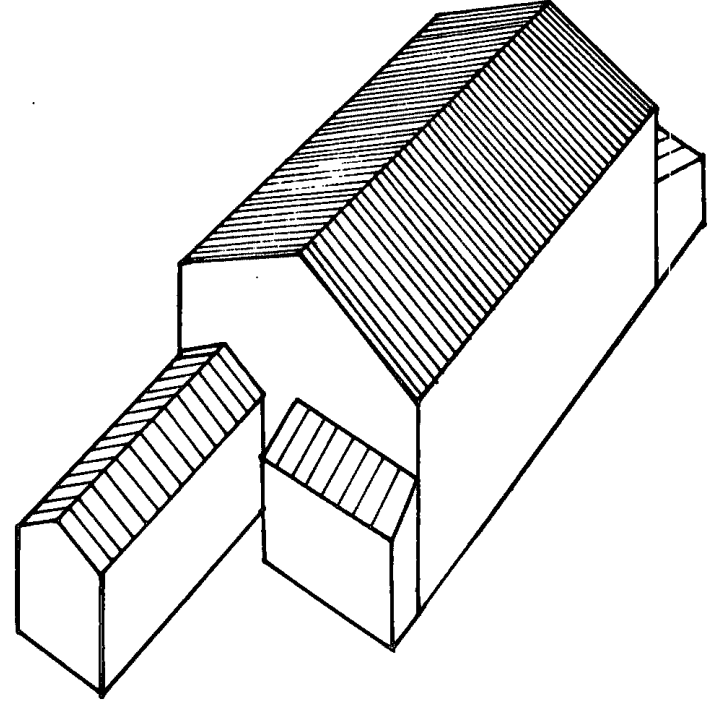

図-7 立体図・「玄関後退」型 2 階建て・妻入り

井高が低くなる問題や 2 階前面の空開口問題は解消され る。

このナガシ部をツノヤとして突き出す手法は北陸地 方, とりわけ滋賀県湖北地方から福井県, 石川県にかけ ての全国でも唯一の前ドマ農家住宅地带においてとくに 発達してきた形式であり注8)，当時としても珍しい手法 ではなかった。したがって，同じ前ドマ形式である「玄 関」型の発展過程において, 従来の下屋形式に代わって このツノヤ形式を採り入れたとしてもなんら不想議はな いのであるが, 結果としてナガシ部は構造上, 主屋部と は完全に独立となり，平面構成上の自由度を飛踓的に獲 得することとなった。そのことが「玄関後退」型という 新しい都市住宅形式の成立・発展を大きく担保してきた といえよう。

\section{2. ゲンカン部およびナガシ部の屋根形式}

本節では, 改めてゲンカン部およびナガシ部の屋根形 式を取り挙げる。

表一2に示すように，ゲンカン部の屋根形式は明治前 期においては下屋形式（下屋からさらに突き出吉形で玄 関庇の付く場合一写真一1 参照一がほとんじであるが,

表一2 ゲンカン部の屋根形式 (「前部台所」系)

\begin{tabular}{|c|c|c|c|c|c|c|}
\hline & $\begin{array}{l}\text { 平 } \\
\text { 全 } \\
\text { 麗 } \\
\text { 根 }\end{array}$ & $\begin{array}{l}\text { 下 } \\
\text { 尿 }\end{array}$ & $\begin{array}{l}\text { 入 } \\
\text { 目 } \\
\text { 资 }\end{array}$ & 切 & 底 & 計 \\
\hline 明治前期 & $\begin{array}{c}7 \\
41.2\end{array}$ & $\begin{array}{c}9 \\
52.9\end{array}$ & & & $\begin{array}{c}1 \\
5.9\end{array}$ & 17 \\
\hline 明㕸後期 & $\begin{array}{c}2 \\
10.0\end{array}$ & $\begin{array}{c}10 \\
50.0\end{array}$ & $\begin{array}{c}3 \\
15.0\end{array}$ & $\begin{array}{c}1 \\
5.0\end{array}$ & $\begin{array}{c}4 \\
20.0\end{array}$ & 20 \\
\hline 大正期 & $\begin{array}{c}1 \\
2.9\end{array}$ & $\begin{array}{c}16 \\
45.7\end{array}$ & $\begin{array}{c}12 \\
34.3\end{array}$ & $\begin{array}{c}3 \\
8.6\end{array}$ & $\begin{array}{c}3 \\
8.6\end{array}$ & 35 \\
\hline 昭和戦前期 & & $\begin{array}{c}40 \\
46.5\end{array}$ & $\begin{array}{c}39 \\
45.3\end{array}$ & $\begin{array}{c}2 \\
2.3\end{array}$ & $\begin{array}{c}5 \\
5.8\end{array}$ & 86 \\
\hline 尌 & 10 & 75 & 54 & 6 & 13 & 158 \\
\hline
\end{tabular}

注）分類不能を除く。 


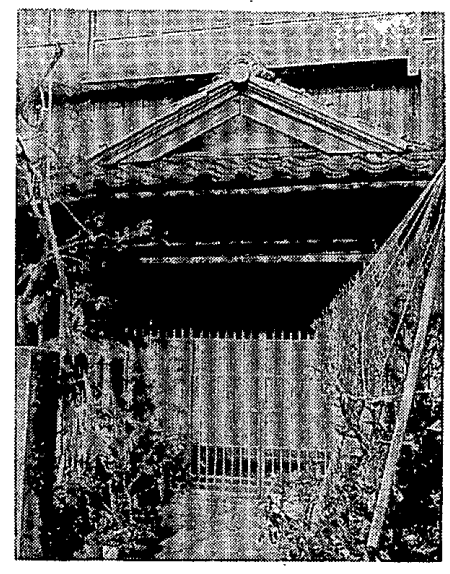

写真一5「玄関後退」型の玄関入母屋屋根
表一3 ゲンカン部の屋根形式（「前部台所」系）

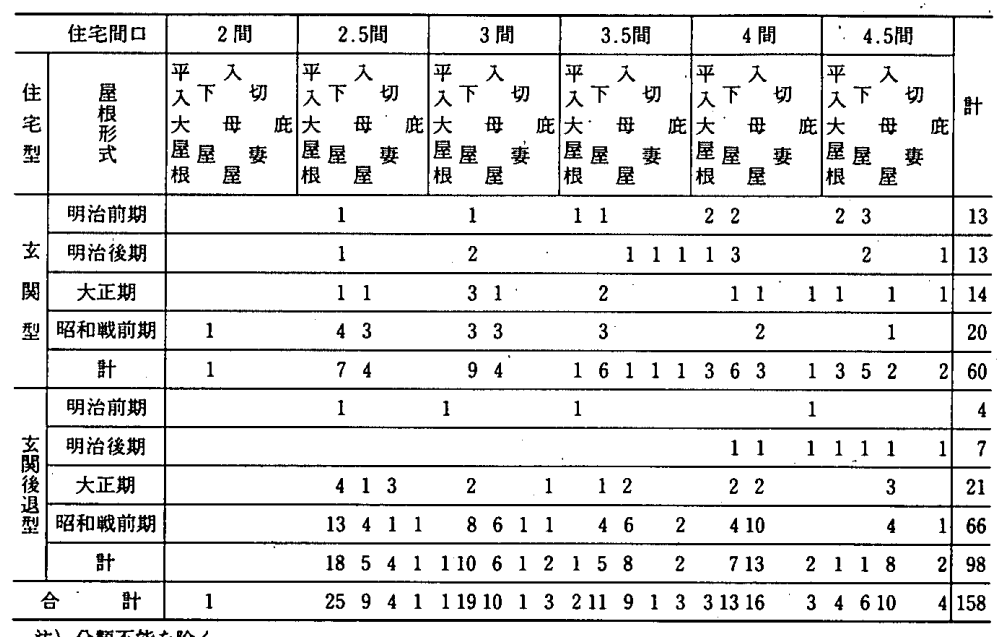

注）分頪不能を除く。
これを表一2,3において「下屋形式」としている。表一 2, 3 における「庇」は主屋から直接玄関庇として突き出 す場合を指している。）が最も多く半数以上を占めてい る。図一1に示した形態である。平入大屋根形式も 41.2 \%を占めるが，これは，図一3 (写真一 2 参照) に示し た形態となる。明治後期になると主屋が 2 階建て化する ことによって平入大屋根形式はなくなるが,下屋形式(図 $-5,6$ 写真一 3,4 参照) はやはり半数を占めている。

大正期でも下屋形式が $45.7 \%$ と最も多いが，注目さ れるのは入母屋形式 (写真一5) の増加である。このゲ ンカン部の入母屋形式は既に明治後期にも認められる が，大正期には急速に普及しはじめ， $34.3 \%$ を示して いる。さらに，昭和戦前期になると，入母屋形式は $45.3 \%$ に増加し，これに切妻形式の玄関を加えると下 屋形式を超えるようになる。これを間口別（表一3）に みると，ゲンカン部の入母屋形式は住宅間口の大きい住 宅ほど多く普及しており，とくに大正期の「玄関後退」 型では 3.5 間間口以上の場合に $7 / 10=70 \%$, 昭和戦前 期では $20 / 31=65 \%$ を占めている。

以上のように，ゲンカン部の屋根形式は，明治期にお いては素朴な下屋形式であったのに対し，2 階化の過程 でゲンカン部の格式意匠性に工夫が凝らされ，次第に入 母屋形式が増加し，かつ主流を占めるようになってきた 状況を読み取ることができる。

次に，ナガジ部の屋根形式を同様に表一 4 から読み取 ると, 明治前期では, 下屋形式（図一1）および平入大 屋根 (図一 3 ) ともに $43.8 \%$ を示している。ゲンカン 部の場合と大差はなく, ゲンカン部とナガシ部が一体的 な構造のもとに設けられていたことによる。

明治後期では 2 階建て化に伴い, 下屋形式が圧倒的に 多くなり約 7 割を占めている。

大正期になると「玄関後退」型の増加に伴いナガシ部 がツノヤとして突き出すために, 切妻形式 (図一7, 写 真一6）が最も多くなり半数近くを占めるようになる。
表-4 ナガシ部の屋根形式 (「前部台所」系)

\begin{tabular}{|c|c|c|c|c|c|c|}
\hline & $\begin{array}{l}\text { 平 } \\
\text { 入 } \\
\text { 詹 } \\
\text { 根 }\end{array}$ & $\begin{array}{l}\text { 下 } \\
\text { 屋 }\end{array}$ & $\begin{array}{l}\text { 切 } \\
\text { 妻 }\end{array}$ & $\begin{array}{l}\text { 寄 } \\
\text { せ } \\
\text { 棟 }\end{array}$ & $\begin{array}{l}z \\
\sigma \\
\text { 他 }\end{array}$ & 計 \\
\hline 明治前期 & $\begin{array}{c}7 \\
43.8\end{array}$ & $\begin{array}{c}7 \\
43.8\end{array}$ & $\begin{array}{c}1 \\
6.3\end{array}$ & $\begin{array}{c}1 \\
6.3\end{array}$ & & 16 \\
\hline 明治後期 & $\begin{array}{c}1 \\
6.3\end{array}$ & $\begin{array}{c}11 \\
68.8\end{array}$ & $\begin{array}{c}2 \\
12.5\end{array}$ & $\stackrel{2}{2}_{12.5}$ & & 16 \\
\hline 大正期 & $\begin{array}{c}1 \\
3.0\end{array}$ & $\begin{array}{c}10 \\
30.3\end{array}$ & $\begin{array}{c}15 \\
45.5\end{array}$ & $\stackrel{3}{9.1}$ & $\begin{array}{c}4 \\
12.1\end{array}$ & 33 \\
\hline 昭和戦前期 & & $\begin{array}{c}31 \\
36.5\end{array}$ & $\begin{array}{c}34 \\
40.0\end{array}$ & $\begin{array}{c}15 \\
17.6\end{array}$ & $\begin{array}{c}5 \\
5.9\end{array}$ & 85 \\
\hline 倝 & 9 & 59 & 52 & 21 & 9 & 150 \\
\hline
\end{tabular}

注）分類不能を除く。

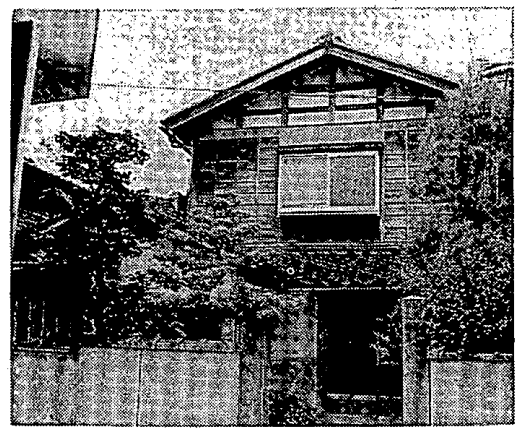

写真一6 大正期における典型的な「玄関後退」型・主屋切妻・ ゲンカン下屋・ナガシ切妻屋根の住宅

下屋形式（写真一 3 参照）は $30: 3 \%$ に減少する。

昭和戦前期では，切妻形式が $40.0 \%$ となるが，寄せ 棟形式（写真一7）の $17.6 \%$ を加えるとツノヤ形式は $57.6 \%$ となる。この寄せ棟形式は明治後期にも 2 件認 められるが急速に普及するのは昭和戦前期である。

この内容をさらに詳しくみたのが表一5である。「玄 関」型の場合はほとんどすべてが平入りあるいは妻入り 
表一5 ナガシ部の屋根形式 (「前部台所」系)

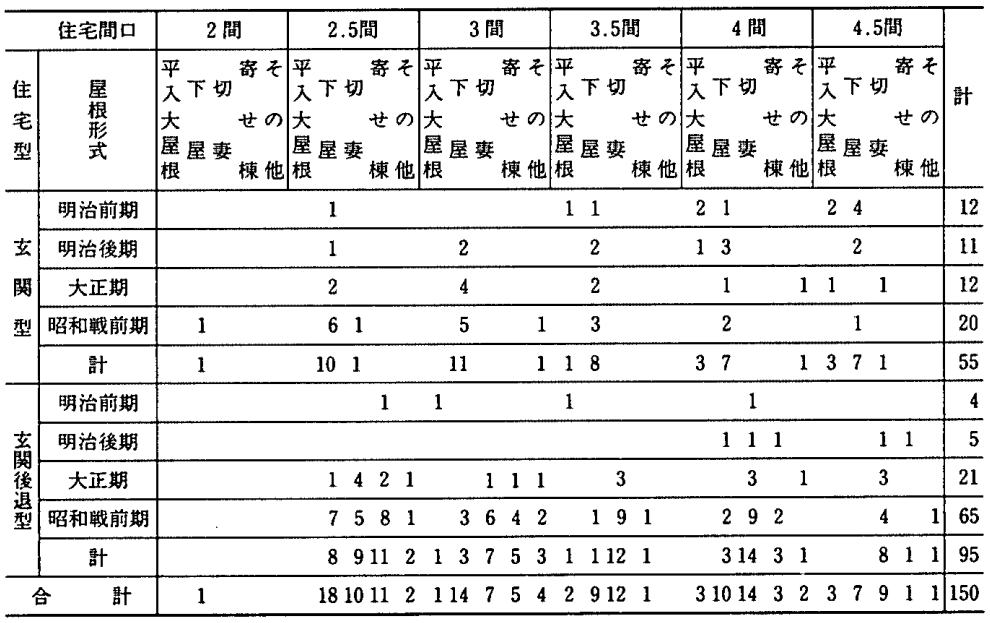

注）分類不能を除く。

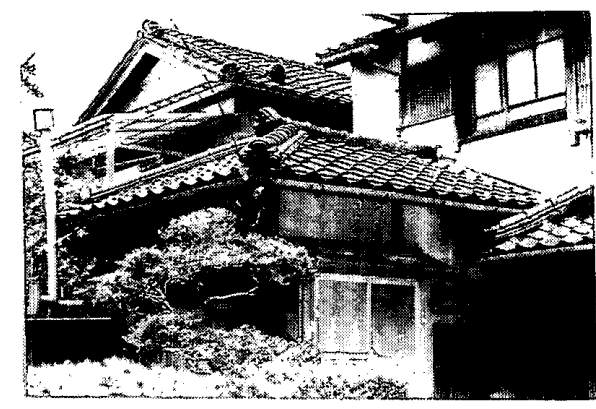

写賣一7ナガシ部の寄せ棟形式

いずれかの主屋に付属する下屋形式である。これに対し 「玄関後退」型ではほとんよ゙すべてがツノヤとして張り 出すが，その形式は 3.5 間間口以上の場合，大正期では $9 / 10=90 \%$ ，昭和戦前期では $22 / 29=76 \%$ と圧倒的に 切妻が多い。一方，小間口住宅が増加する昭和戦前期の 3 間間口以下に注目すると寄せ棟形式（12 戸）が切妻 形式 (11戸) と肩を並べるようになる。さらに, より 小間口の 2.5 間間口に注目するとむしろ奇せ棟形式の方 が多くなる。なお， 2.5 間間口程度の小間口住宅では寄 せ棟に分類したが実際は片流れ形式でかつ奇せ棟（写真 一8）のものが多い。このように小間口ほどナガシ屋根 の形状が寄せ棟となるのはその間口幅が狭くなった (1.5 間以下) 場合の屋根形状（とくに破風面）の貧相 さを補おうとする意匠意識によるものと考えられる。

以上のように，ナガシ部の屋根形式は，「玄関」型で は下屋形式が一般的であったが,大正期以降,「玄関後退」 型ではツノヤとなり，その形式は切妻を主とし，間口の 小さいナガシ屋根では寄せ棟形式が現れてきた。

\section{3. 住宅の外観における変容過程・要約}

以上, 1,2 節の結果を総合して, 住宅の外観面からみ た住宅様式の変容過程を要約する。

旧武士居住地における住宅様式は，明治前期における 妻入りあるいは平入り平屋建て直家形式の「玄関」型か
ら出発し，2 階化することによって「玄関後退」型が発 生する。

その初期段階は主屋屋根は 2 階建て妻入り (切妻) で あるがとくに 3 間間口以下の小間口住宅では平入りも多 く存在した。また，この段階では玄関は下屋であり，ナ ガシはツノヤ形式の切妻屋根であった。この初期段階の 「玄関後退」型はとくに2 階切妻破風面を束と賁を格子 状に組む「アズマダチ」とする素朴で美しい外観によっ て特徴づけられる。

その後, 昭和期に入ると主屋屋根は次第に妻入りが主 流を占めるようになるとともにその屋根形状は入母屋屋 根が増加し，玄関も入母屋に変化する。

この過程を写真で示すと, 前出の写真一 1,20 段階か ら, 写真一 3 を経て, 写真一6の段階で「玄関後退」型 が成立する。そして最終的には写真一 9 となって「立閣 後退」型は外観様式の面でも完成する。この段階では主 屋入母屋屋根の下に 2 階の空が出空風に張り出し, かつ ての束と貫による「アズマダチ」の素朴な意匠は消える が，一方，玄関も入母屋の「威風」を備えた意医が出現 する。

また一連の本研究では直接の分析対象とはしてこな かったが，もともと下級武士階級住宅であった「玄関」 型の時期からこれら住宅はすべて門構えを有していた。 それが, 写真一 1,2 から写真一 3 を経て, 写真- -6 , 写真 一 9 となるに従い前面道路境界線に接する塀や門構えは 次第に格式性を備えたものに変容してきたことを示唆し ている主9!。

要するに, 住宅の外観からみた住宅様式の変容過程は, 一言で要約すれば「格式化」の過程であった。それを支 えてきたのは，明治後期から勃興する（地方都市におい ては）官吏などに代表される都市「中流階層」非109 の住 居観であった。 


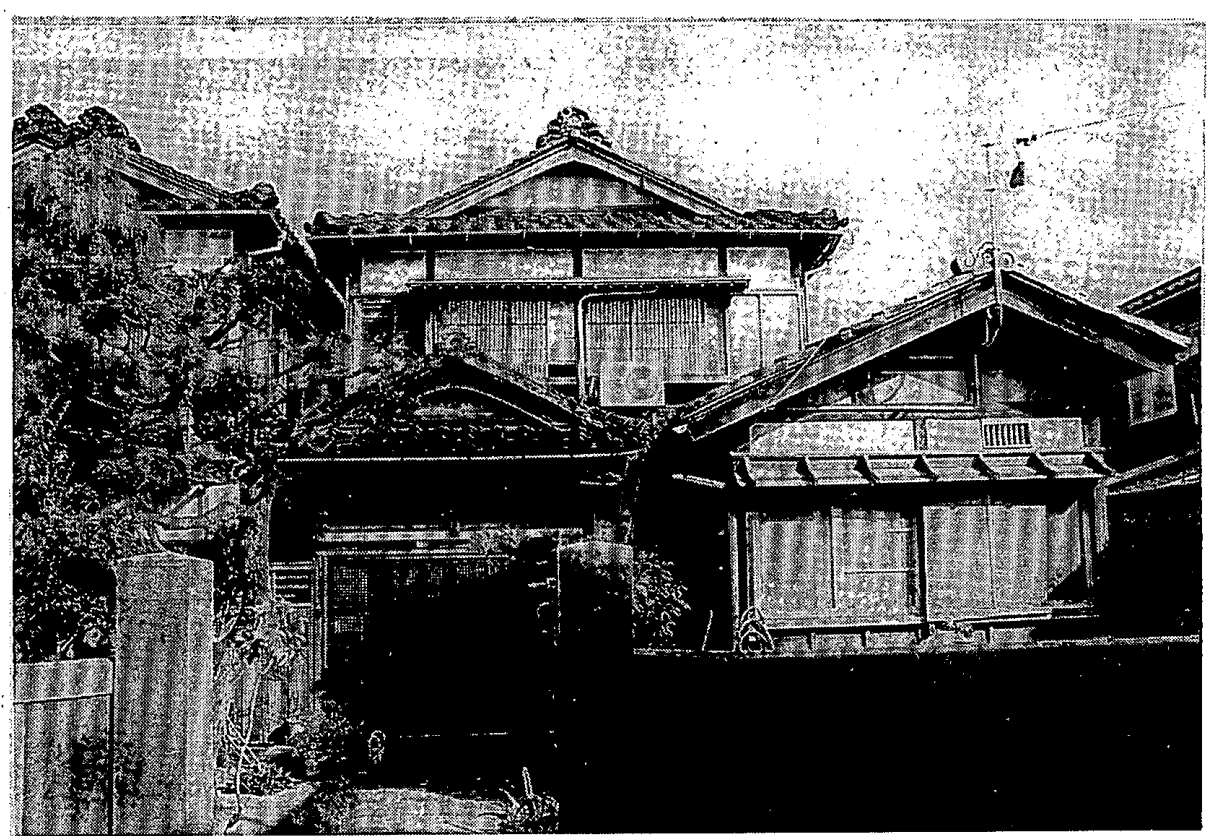

写真一9 昭和戦前期の典型的外観をもつ「玄関後退」型・主屋入母屋・ゲンカン入母屋・ナガシ切妻屋根の住宅

補 遺. 前部台所系住宅注11における昭和戦前期までの ザシキの位置付けと就寝状況

一連の本研究は実態調査に基づく資料をもとに，一貫 して住宅の「物的」側面に限定して論考を進めてきた。 そこでの最も基本的な論理の一つは，「玄関後退」型を 成立させた要因は「正式」のザシキを確保するための住 宅の 2 階化にあった，ということであった。本節ではこ の考察を補強するために, 戦前住宅について主として就 寝と接客面から若干の「住まい方」調査を行った結果を 「補遗」として報告し，ひとまず一連の本研究を閉じる こととしたい。

用いた資料は，戦前および戦後の住まい方を知るため に行った平成元年 10 月〜 12 月の居住者ヒアリング調查 の結果である。調查対象は前部台所系の既採取平面 189 戸から無作為に抽出した120戸であり，このうち調査が 可能であった世帯は70 世帯であった。さらに，戦前か ら居住している世帯は 28 世帯 $(40 \%)$ であったが, 当 時の状況（主に戦前期）を把握できたものは 22 世帯で あった。

このようにサンプル数が限られているので事例報告と しての域を出るものではないが，それでも一定の傾向が 認められ，住まい方における当時の状況を読み取ること "ができる。

はじめに,ヒアリング結果のうち代表的な例を挙げる。 前々稿（No.5）平面図一16に示した「玄関後退」型・ $\lceil 2 \cdot 2 \cdot 2$ 構成」の住宅は建設時期は「明治後期」であ るが，現居住者が住みはじめたのは昭和 13 年であった。 当時の居住者は夫婦のみであり, 1 階のザシキで就寝し た。ここには, 簡単なトコ, 仏壇, エンが備わり，半間 の押入も設けられている。接客は 1 階ザシキでも行われ
たが，正式には普段は空き室であった 2 階のザシキが使 用された。

戦後間もなくの, 最も家族人数が多い時には, 長男が 2 階の洋間, その隣室の 4.5 畳が長女の寝室に当てられ, 幼い二女, 二男は夫婦とともに，1階のザシキおよびイ マ(ナンド)，で適宜就寝した。

図一8の「玄関」型・「2・2・2 構成」の住宅は, 大正 14 年に建設された。建設当初は, 夫婦および女子 4 人が, 1 階のザシキとナンドにわたって就寝していた。男子は 2 階の 6 畳に長男（19 歳）が，4 畳に次男 (9 歳) がそ れぞれ 1 室与えられて就寝していた。

2 階のザシキは主ザシキとして空き室であった。

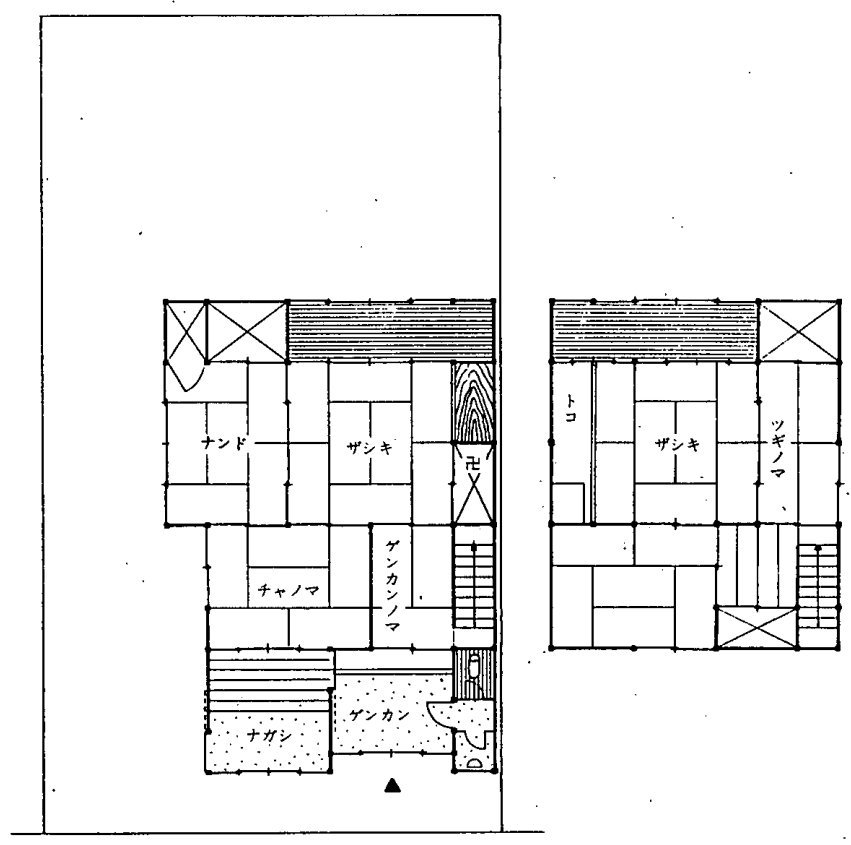

図-8、立関」型 $\cdot\lceil 2 \cdot 2 \cdot 2$ 構成」(大正期) 
図一9の「玄関後退」型・「2・1・1B構成」の住宅は 昭和 4 年に建設された。当初は, 老夫人（若夫人に対し て）とその子供である女子 3 人の計 4 人が 1 階ブッマで 集中就寝し, 若夫婦は 2 階の後部 4.5 畳で就寝した。客 の動線は, ゲンカン, ゲンカンノマ, 階段, 2 階ゼンシ ッ，主ザシキの順となる。主ザシキは前部に位置して 6 畳と小規模であるが, 1.5 間のトコにエンを備えている。

図一10の「玄関」型・「2・1・1B構成」の住宅は昭 和 4 年に建設された。戦前は, 老夫婦（若夫婦に対して の意) が 1 階ザシキで就蔓し，若夫婦は 2 階の前部 6 畳 で就寝した。客の動線は, 前図と同様, ゲンカン, ゲン カンノマ, 階段, 2 階ゼンシツ, 主ザシキの順となる。

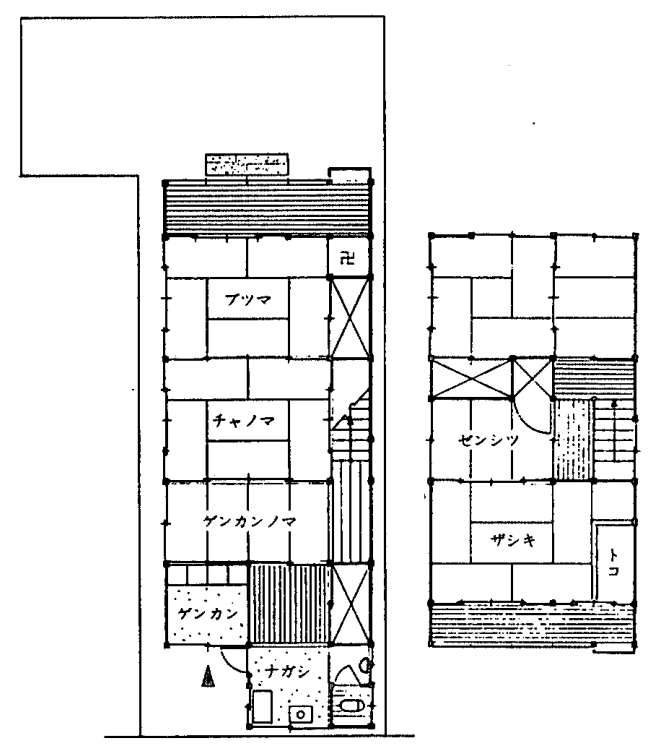

図一9「玄関後退」型 $\cdot\lceil 2 \cdot 1 \cdot 1 \mathrm{~B}$ 構成」(昭和戦前期)

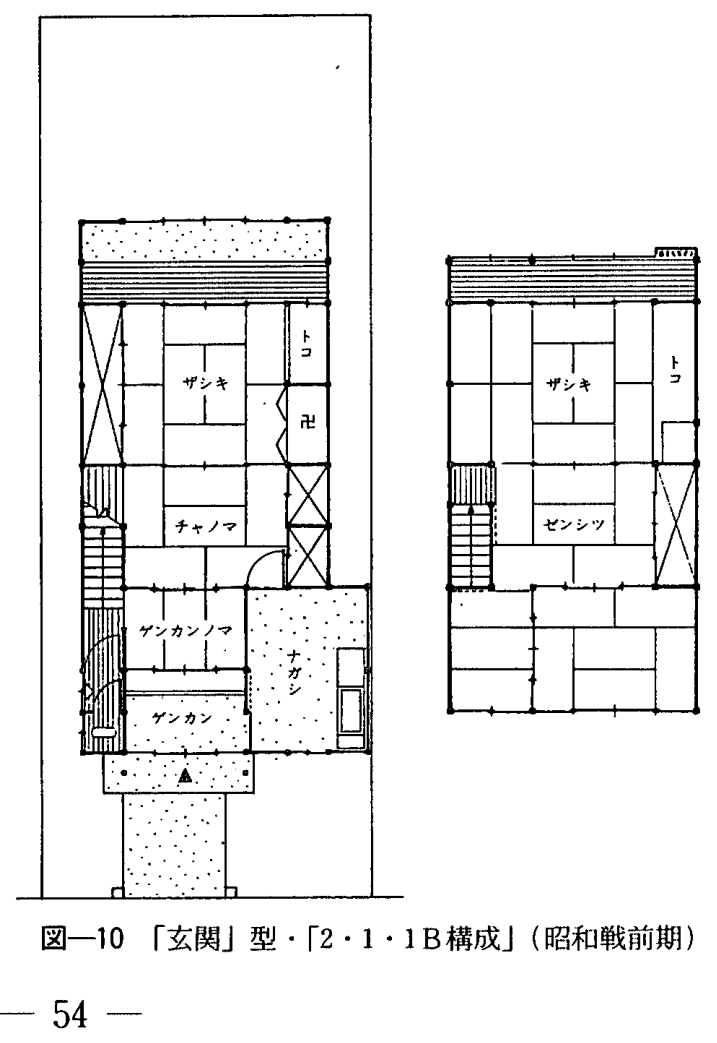

主ザシキは，10 畳の規模をもち，2 間のトコにエンを備 えている。

戦後間もなくの時期に, 老夫婦, 若夫婦とも夫が亡く なっており，この夫人 2 人と若夫婦の長女 (当時 17 藏) が 1 階ザシキで就寝した。2 階は前部の 6 畳に長男, 3 盢に二男が就寝した。主ザシキおよびゼンシツは，空き 室とされていた。

次にサンプル全体から読み取れた内容を述べると，ま ず， 2 階のザシキは主ザシキであることから，ここが寝 室に専用あるいは兼用されることはなかった。

これに対し，1階のザシキはブッマを兼ねて扮り,「2・ $2 \cdot 2$ 構成」では半数以上が葠室としては使用していな い。寝室に使用しない住宅では比較的，日常の接客（特 別の行事等ではないという意味）に使用していた。しか し一方，1階ザシキは隣室にナンドがあるにもかかから ず，主寝室として使用する場合も相当数認められる。1 階ザシキは，トコ，エンを備えている。そのため主人室 としての格付けを重んじる家庭では，主人を中心とする 寝室として使用されていた。なお，子供が幼い場合は， 1 階ザシキに限らず親である夫婦とともに就葠するし， 隣室のナンドと合わせて主人夫婦と子供たちが就寝する ものも，この範疇に含めている。

ナンドは, 本来の性格から寝室として使われるが, 1 階ザシキとナンドは襖で仕切られているだけなので，た とえば老夫婦と若夫婦が隣り合わせに就寝することは原 則としてない。言いかえれば，1階ザシキあるいはナン ドは，原則的にはどちらか一方だけが瞉室として使用さ れることになる。ナンドが寝室として使われる場合，そ の使用者は主人夫婦か老人 (女性) であるが，その他女 子を中心とする集中就寝の場所にもあてられた。

2 階の（主ザシキ以外の）居室を寝室に使用すること も，ほとんどの場合に認められる。使用者は若夫婦か子 供いずれかであり，主人夫婦あるいは老人が使用するこ とはなかった。子供の場合，2階の対象は男子が多い。 男子に一人 1 室が与えられている場合もまれに認められ るが，その場合でも女子は 1 階に集中就寝しでいる。

$\lceil 2 \cdot 2 \cdot 1$ 構成」および「2・1・1構成」では, 1 階奥 の間がザシキ兼ナンドであるため，ここに，主人夫婦， あるいは老人や幼い子供が就寝せざるを得ない。一般に， 室数にゆとりがない限り集中就寝であり，とくに子供の 場合はそうである。「2・2・1 構成」や「2・1・1構成」 では 1 階ザシキがナンドを兼ねるので，ここに姑，嫁， 成人に近い女子が集中就寝していたケースや，成人男子 でさえ嫁が来るまで親夫婦と集中就寝していたケースも 採取されている。なお, 夫婦, 子供 9 人の合計 11 人家 族が同時期に居住した例があり，当然集中就寝の程度も 厳しかったことが想像されるが，この場合でも2 階ザシ キは空き室とされていた。 
また，戦前の住まい方を採取した 22 例中，チャノマ を就寝場所としている例は 1 例も存在しなかった。かつ て西山外三が示した食寝分離の原則は，金沢の「中流住 宅」においてもあてはまっていたことを示している。

以上のように，明治後期から2 階建て化が始まったの は，仏間を兼ねた半ば私的な 1 階の「ザシキ」ではなく， 2 階に「正式」の座敷を構えるためであったことが確認 される。

\section{結 語}

以上，一連の本研究を通して，旧下級武士居住地にお ける「玄関」型住宅を祖型しして，明治後期以降，「玄 関後退」型住宅が成立してきたこと,および, その成立・ 変容の過程と要因を検討してきた。

稿を結ぶにあたり，改めて本研究の意義を要約すると 以下のようになるであろう。

1. 地方都市における都市「中流住宅」系譜の発掘

これまでも既に，我が国中産階級住宅の源流は，旧武

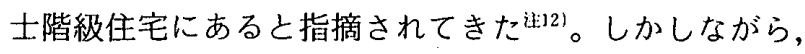
その源流から都市中流住宅の成立に至る過程を実証的に 論じたものは見当たらないといえよう主131。

一方，旧下級武士住宅を対象とする優れた研究もいく つか存在している注14)。しかしながら，それらの多くは 建築歴史学の視点から藩政期における住宅の考証それ自 体を直接の目的としてお゙り，現代住宅につながる系譜と して，その発展過程を実証的・系統的に論じたものはな い。

この点において，本論は金沢という日本の代表的な地 方都市を対象として，旧下級武士階層の住宅から現代住 宅につながる都市住宅の系譜を抽出・考証したことに第 1 の意義が見いだせると思われる。

また，日本における明治以降の住宅の歴史は，かの幸 田露伴の主張 ${ }^{(15)}$ を実証するかのごとく，一面専用住宅 化の歴史でもあった。その視座からみれば，本研究は， 農業あるいは商業併用住宅に対置する，専用住宅系都市 住宅の系譜を発掘してきたことになる。

さらに,この旧下級武士住宅を祖型とする専用住宅は, いわゆるトオリニワを持ち後部台所系である町家系住宅 に対置する，前部台所系住宅として，都市住宅の二大潮 流の一つを構成していたことを考証した。

\section{2. 接客・格式空間の優先}

この旧下級武士階級に起源をもつ都市型住宅は，下級 といえよ゙も武士階級の住宅であっただけに，接客・格式 空間を優先していた。祖型としての「玄関」型はゲンカ ン, ゲンカンノマ(小間), ザシキの接客・格式空間列と, ナガシ，チャノマ，ナンドの生活空間列，すなわち，い わゆる「ハレ」と「ケ」の空間列を峻別しており，かつ 「ハレ」空間を主体に構成しているところに特徴がある。
ところで，明治以降の日本の指導層を形成したのは旧 中・下級武士階級出身者であった。さらに横山俊夫が提 出し，梅棹忠夫济16)が敷衍したように，日本の近代化 (シ ビリゼーション) 過程は武士 (サムラ.イ) 文化の大衆化 (サムライゼーション) 過程でもあった。とすれば，日 本の近代化過程において当時勃與しつつあった「中流階 層」を対象とする専用住宅の変容過程は，接客・格式空 間確保に腐心した歴史でもあったはずである。したがっ て, 明治以降,「玄関」型から「玄関後退」型に変容し ていく直接の動機が，2階に「正式」の接客・格式空間 としてのザシキを確保することにあったことは，この歴 史的文脈の中では必然的な結果であった。さらに，屋根 形式における切妻から入母屋化，あるいは玄関の入母屋 化，門構えの充実等も，体面や格式を重んじるサムライ 文化の直系的末裔としての都市中流階層にとっては当然 の帰結であった。

このように考えると, 旧下級武士階級住宅を祖型とす る住宅系の住宅平面形式および住宅（外観）様式の成立 亡変容過程は，日本の近代社会成立期における都市中流 階層の生活之思想をまさに象徵するものであったといえ よう。

3. 間口と住宅型の関係

本研究の第 3 の意義は, 現実には決定的な意味を持ち, その重要性については自明であるにもかかわらず（ある がゆえに）研究的には注目されることの少なかった宅地 間口および住宅間口に着目してきたことである。

宅地間口および住宅間口は明治以降，狭小化の過程を たどってきたことを示したが，その過程こそが「玄関」 型から「玄関後退」型を産み出すもうひとつの大きな動 機であった。間口の縮小化にもかかわらず, 2 階化によっ て「ザシキ」空間を確保する一方で, ナンド, チャノ、, ナガシの生活空間を温存・確保（その結果，住宅規模の 拡大）しようとする住要求の過程がナガシの前面への張 り出しと屋根形状の下屋からツノヤへの変化を産み出し た。

さらに「玄関後退」型において間口別に住宅型「構成」 が明瞭に定式化できることを示すことによって，とくに 都市住宅の場合, 住宅型および住宅型「構成」は宅地（住 宅）間口に規定されて成立，変容してきたことを論証し た。この結果を敷衍すれば，住宅型や住宅平面構成等の 検討に際しては，これまでの「列構成」などの視点に加 えて，住宅間口の検討が重要な視坐であることを改めて 示したことになる。

\section{4. 民衆の民衆による民臬のための建築}

「玄関」型から「玄関後退」型への変容, および間口 別の「玄関後退」型各構成の成立の動機とその変容過程 を整理してきた。言いかえれば，当時の社会的・経済的 外部条件と居住者の価值観に基づく住要求に対応して新 
しい都市住宅型が成立してきた過程を整理してきたこと になるが, それは一面, 時代に対応する居住者の創意工 夫という, 民衆の巧まざる智惠の過程を検証することで もあった。明治初期から数えても, 昭和戦前期まで約 80 年程度の期間において, 一たび状況が変化すれば, 一人の建築家や計画家が介在することもなく，すなわち， 江戸時代の庶民住宅について露伴が指摘したように，自 らの階層に適わしい住宅型を「何人の意匠によれるとも 無く，次第々々改良を積みたる結果として殆ど一定の様 式を成すに至」出17) たし，成しうることの検証でもあっ た。その意味では, 一連の本研究は, 明治以降, 昭和戦 前期にかけての, 日本の代表的な地方都市, 金沢市にお いて展開された，日本の「中流階層」の一つの見事な Architecture without Architects ${ }^{\text {i:181 }}$ の存在と, その産み 出される過程への照射でもあった。

\section{注}

1) 文献 1) 6)

2）一連の本研究では資料を昭和戦前期までに限定している のでこのように表現しているが，夷際には高度経済成長 期以降，旧市街地においても建て替えのはじまる昭和 40 年頃まで，旧市街地における代表的住宅型の一つであっ た。

3) 文献 7), 8)

4) 文献 9)

5) 北陸地方では，力ヤ苜 (サス組) から板蒀，さらにカワ

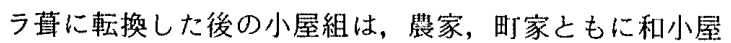
組よりもノボリ梁構法が一般的であった。

6)この意匠は「玄関」型の平屋建てにもみられた（写真一1 参照)。しかし平屋建ての場合は前面の下屋に遮られ, 破 風面も小さいため目立つことはなかった。一般に, 福井 県から富山県の北陸地方において, 入母屋あるいは笴せ 棟のカヤ蒙から板苜あるいはカワラ苜の切妻屋根になっ た時, 破風面はこの様式となった。この背景には全国で も唯一の妻入り地带であることが関係しており，玄関正 面の破風面への意匠意識が強く働いた結果とみることが できよう。その意味では北陸地方における典型的な伝統 的住宅意匠梯式といえよう。

しかし, この様式も後に述べる入母屋化の趨勢の中で 消減の方向にある。なお，この様式が最も発達した富山 県属波地方の農家住宅では，この様式を「アズマダチ」 と呼んでいる(参考文献 11) 参照)。石川県の農家住宅 では「アズマダテ」と呼称する地域もあるが, 本稿で論 じてきた都市住宅については，通常の呼称はないようで ありそその呼称例を採集することはできなかった。

7) 民家学における統一的用語として用いているが, 北陸地 方ではツノヤと呼ふことはない。北陸地方ではカグラと 呼ぶ場合が多い。

8）文献 10）参照。

9）門構えや塀は階層性を示すステータス性の最も強いもの であるから，厳密には階層を同定して比較しなければな らない。したがって,ここではあくまでも推測の域を出 るものではない。

10）文献 4), p. 40 参照。なお, 文献 12）p. 45 では「中流住
宅」に居住する(大部分の) 階層を「新政府に出仕する 官僚, 大資本に低存する高級社崱をはじめとして, 技術者, 医師, 法律家, 教育者, 一部の軍人」と想定している。 ただし，一連の本研究で展開している「中流住宅」はい ずれも女中部屋をもたないことからも明らかなように， 木村博士が展開した「中砶卜型体宅」(必ずといってよい ほど女中部屋を供えていた)などに代表される「中流体宅」 に比較して，一ランクト層の，つまり，より「焦民」階 層に近い都市居住者の住む「中流住宅」であったとみる ベきであろう。

11）一連の本研究で諭じてきた旧卜級武上住宅を礼型とする 「玄関」型およびその発展形態としての「玄関後退」型 住宅はいずれも住宅前部に台所を持ち，後部に台所を持 ついわゆる「トオリニワ」型の町家住宅とは対照をなし ている(文献 4)，No.4参照) のでここでは「玄関」 型と「玄関後退」型を総称して前部台所系住宅と表現し ている。

12）たとえば文献 12) p. 98。

13）武士階級住宅から都市中流住宅が成立する過程を詳細に 論じたのは，おそらく木村徳国博上をもって嚾矢とする であろう（その内容は氏の学位諭文一「日本近代都市独立 住宅様式の成立と展開に関する史的研究」に収妨れて いるがその骨子は文献 12)にまとめられている)。しかし， この博士の優れた研究も中廊下型住宅の成立，ついで居 間中心型住宅の成立という，二つの住宅様式の成立過程 を様式史的に展開しているものであって, 武士住宅から の系譜を直接的に論証・展開しているものではない。博 士は「いまや中流住宅に変質しようとする在来和風住宅, 北田氏のいう『以前旧体の日本宅』が江戸時代のいか公 る流れをひくものであるかについては，現代のところ， 江戸時代のさまざまの住宅が完全に明らかにされていな いので明確に断言することができない」(文献 12）p.98) として, 直接的な系譜の展開を行っていない。

なお，この木村博士の展開した中鄉下住宅および居間 中心型住宅の成立と展開について, 総合的な再検討と新 たな視点を提示したものに九州大学青木正夫博士 (当時) を中心とする研究者グループの研究がある。この研究は きわめて示唆に富む優れたもの（その要旨は文献 13）に まとめられている)であるが，本稿とは直接的には関係 しないのでその論評は行わない。

14）たとえば文献 14)。

15）文献 15) pp. 92 94。

16) 文献 16)

17）文献 15）p.85。なお，伊藤忠太はこのような発展形態を 「進化主義」と名付けていた(伊藤忠太, 「進化論」, 建 築雑誌 323 号, 一青木正夫博士, 文献 13) p. 13 参照)。

18）文献 17)

\section{参考文献}

1) 玉置伸俉, 近藤達男 : 歴史的既成市街地内居住地におけ る宅地間口の収束性について一金沢市におけるケ一 ス・スタディー, 日本建築学会論文報告集, 第 302 号, pp. 107 - 119, 昭和 56 年 4 月

2) 玉置伸俉, 近藤達男 : 歴史的既成市街地内居住地におけ る住宅間口と住宅平面型の関係 一金沢市におけるケー ス・スタデイ No.2一, 日本建築学会論文報告集, 第 317 号, pp. 105 115, 昭和 57 年 7 月 
3）玉置伸俉, 近藤達男：歷史的既成市街地内居住地におけ る住宅型と設備空間の関係 一金沢市におけるケース・ スタディ No.3一, 日本建築学会論文報告集, 第 336 号, pp. 100 111, 昭和 59 年 2 月

4）増田達男, 玉置伸俉：残存住宅調査からみた旧武士居住 地における明治以降の住宅平面型の変容に関する研究 一金沢市におけるケース・スタディ No.4一，日本建築 学会計画系論文報告集, 第 403 号, pp. $33 \sim 42,1989$ 年 9 月

5）増田達男, 玉置伸俉 : 旧武士居住地における明治以降の 住宅平面型の特徵とその変容に関する研究 一金沢市に おけるケース・スタディ No.5一，日本建築学会計画系 論文報告集, 第 409 号, pp. 95 107，1990 年 3 月

6）王置伸俉, 増田達男：「玄関後退」型住宅の成立亡変容過 程に関する研究 一金沢市におけるケース・スタディ No. 6-, 日本建築学会計画系諭文報告集, 第 413 号, pp. 49 60, 1990 年 7 月

7) 島村 萛, 増田達男ほか：金沢における武士住宅の研究・ その 1 一武士住宅における諸空間の特徵一, 日本建築 学会北陸支部研究報告集, 第 32 号, pp. $241 \sim 244$, 平成 元年 6 月

8）島村 昇, 増田達男ほか：金沢における武士住宅の研究 · その 2 一武士住宅の平面構成について一, 日本建築学 会北陸支部研究報告集, 第 32 号, pp. 245 248, 平成元 年 6 月

9）島村 昇，増田達男ほか：金沢における武士住宅に関す る研究・その 2 一平面分析による足軽住宅の居住空間
一, 日本建築学会北陸支部研究報告集, 第 31 号, pp. $215 \sim 218$, 昭和 63 年 6 月

10）王置伸俉ほか：北陸地方における農家住宅の変容過程に 関する研究（その1）－福井県嶺北地方における農家住 宅に関する研究一, 財団法人新住宅建築研究所報, No. 11, pp. 113 132, 1984

11）玉置伸俉ほか：北陸地方における農家住宅の変容過程に 関する研究（その2）一富山県における農家住宅に関す る研究一, 財団法人新住宅建築研究所報, No. 12 , pp. $151 \sim 168,1985$

12）木村徳国：明治時代の都市住宅一中産階級住宅の発生亡 中廊下形住宅様式の成立一, 太田博太郎編「近代住宅史」, 雄山閣出版, 昭和 44 年 5 月

13）青木正夫：明治以降の住様式の変化・発展に関する考察, 財団法人住宅建築研究所報, No. 12, pp. 13 61，1985

14）大河直躬：江戸時代の中・下級武士住居と近代都市住居, 「日本建築の特質一太田博太郎還暦記念論文集」. 所収, pp. 418～456, 中央公論美術出版, 昭和 51 年 10 月

15）幸田露伴：露伴全集 第 9 巻, 蝸牛会編, 岩波書占, 昭 和 29 年 12 月

16）梅棹忠夫, 石毛直道編：「近代日本の文明学】, 中央公論社, pp. $96 \sim 97$, pp. 158 161, 昭和 59 年 5 月

17) Rudofsky Bernard: ARCHITECTURE WITHOUT ARChITECTS, U.S.A. Connecticut Printers. Inc. 1964

(1990 年 7 月 10 日原稿受理, 1990 年 11 月 7 日採用決定） 